\title{
ARE CONSUMERS ALWAYS GREENER \\ ON THE OTHER SIDE OF THE FENCE? \\ FACTORS THAT INFLUENCE GREEN \\ PURCHASE INTENTIONS - THE CONTEXT \\ OF CROATIAN AND SWEDISH CONSUMERS
}

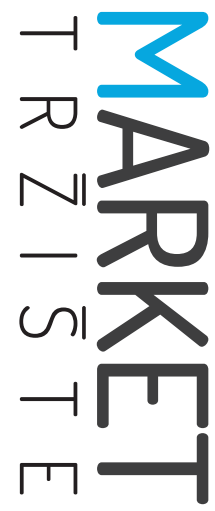

\section{JESU LI POTROŠAČI UVIJEK "ZELENIJI" S DRUGE STRANE OGRADE? ČIMBENICI KOJ UTJEČU NA NAMJERU “ZELENE” KUPOVINE - KONTEKST HRVATSKIH I ŠVEDSKIH POTROŠAČA}

Market-Tržište

Vol. 32, Special Issue, 2020, pp. 99-113

UDK 502.12:658.8:658.82(497.5)(485)

DOl http://dx.doi.org/10.22598/mt/2020.32.spec-issue.99

Preliminary communication

\begin{abstract}
Branka Dropulića , Zoran Krupkab
a University of Zagreb, Faculty of Economics \& Business, J. F. Kennedy Square 6, 10000 Zagreb, CROATIA, e-mail: bdropulic@efzg.hr

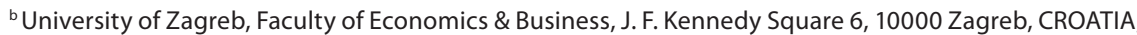
e-mail:zkrupka@efzg.hr
\end{abstract}

\begin{abstract}
Purpose - Seeking to understand sustainability through the concept of green marketing mix and green consumer behaviour better, this paper examines their role in expressing green purchase intentions. Aiming to get a better insight into green consumer behaviour, it explores two important psychographic and behavioural variables: environmental awareness and perceived consumer effectiveness. The concept of both marketing mix and green consumer behaviour are examined in two very different contexts (Croatia and Sweden).
\end{abstract}

Design/Methodology/Approach - To conduct the research, a self-completed highly structured questionnaire was designed. Green product characteristics were defined through the concept of marketing mix, while green consumers were defined according to their demographics and two psychographic and behavioural variables. The research was conducted among Croatian and Swedish consumers.

\section{Sažetak}

Svrha - Radi boljeg razumijevanja održivosti kroz koncept zelenog marketinškog miksa i zelenog ponašanja potrošača, ovim radom se istražuje njihova uloga u izražavanju namjere zelene kupovine. Da bi se dobio bolji uvid u zeleno ponašanje potrošača, u radu se istražuje važnost ekološke osviještenosti i percipirane mogućnosti djelovanja potrošača kao psihografske, odnosno bihevioralne varijable. Oba temeljna koncepta ovoga rada, zeleni marketinški miks i zeleno ponašanje potrošača, istražena su u dvama različitima kontekstima (Hrvatska i Švedska).

Metodološki pristup - Za potrebe istraživanja kreiran je visokostrukturirani upitnik. Karakteristike zelenog proizvoda definirane su kroz koncept marketinškog miksa, dok su zeleni potrošači definirani kroz demografska obilježja te psihografske i bihevioralne karakteristike. Istraživanje je provedeno na uzorku hrvatskih i švedskih potrošača. 
Findings and implications - The research showed that the two samples, despite differences, have two factors of influence on green purchase intention in common: perceived higher quality of green products and environmental awareness. Both Croatian and Swedish consumers showed willingness to pay the premium price for green products, which shows the important role of price as a quality communicator of green products. Eco-labels, once they become a standard as is the case of the Swedish market, no longer have strong influence on green purchase intention.

Limitations - The main limitation of this research is the fact that only low involvement products were used in the questionnaire.

Originality - The main contribution of the paper is a deeper insight in purchase intentions of green consumers. The factors that drive green purchase intentions are observed in two different cultural, political and economic contexts, which adds value to green consumer understanding, but also contributes to better understanding of green product management.

Keywords - green products, green marketing mix, green consumers, purchase intentions, Croatia, Sweden
Rezultati i implikacije - Istraživanje je pokazalo da su percipirana kvaliteta zelenih proizvoda i ekološka osviještenost potrošača čimbenici koji utječu na namjeru zelene kupovine u oba istraživana konteksta (usprkos njihovim razlikama). I hrvatski i švedski potrošači pokazali su spremnost plaćanja više cijene za zelene proizvode, što upućuje na važnu ulogu cijene kao pokazatelja kvalitete zelenih proizvoda. Kada oznake eko postanu standard industrije, kao u slučaju Švedske, one više nemaju utjecaj na namjeru zelene kupovine.

Ograničenja - Glavno je ograničenje istraživanja činjenica da su u istraživanju korišteni proizvodi s niskom uključenošću potrošača u proces kupovine.

Doprinos - Glavni je doprinos rada u dubljem razumijevanju kupovne namjere zelenih potrošača. Osim toga, čimbenici koji pokreću namjeru zelene kupovine promatrani su u dvama različitima kulturološkim, političkim i ekonomskim kontekstima što povećava vrijednost razumijevanja ponašanja zelenih potrošača, ali isto tako doprinosi boljem razumijevanju upravljanja zelenim proizvodima.

Ključne riječi - zeleni proizvodi, zeleni marketinški miks, zeleni potrošači, namjera kupovine, Hrvatska, Švedska 


\section{INTRODUCTION}

Defining products as green remains ambiguous due to the fact that there is no such product which does not have a negative influence on the environment in some stage of its lifecycle. For the purpose of this research, green product can be defined as a "product that was manufactured using toxic-free ingredients and environmentally friendly procedures, which is certified as such by a recognized organization" (Kumar \& Ghodeswar, 2015). 'Greening the marketing mix' and producing green products sets grounds for achieving a sustainable competitive advantage (D'Souza, Taghian, Lamb \& Peretiatkos, 2006).

In order for practitioners and researchers to improve the understanding of the green marketplace, understanding the green marketing mix is not enough. It is highly important to understand the shift in consumers' behavioural patterns since the advantages for consumers from sustainable consumption are mainly psychological (Abdulrazak \& Quoquab, 2018). It makes them feel good about themselves and encourages self-improvement and social interaction. But still, it is assumed that consumers with different cultural background are driven by different factors (Haron, Paim \& Yahaya, 2005). If we look only at the level of the EU, consumers in general show a high level of concern about the environment and see it as a problem that affects them as individuals. On the other hand, analysis on the level of individual EU member states shown there are inequalities between them. For instance, protecting the environment is more important for consumers from Cyprus and Sweden than it is for consumers from Poland and Croatia (European Commission, 2017). This difference in attitudes is something that reflects on consumers' green purchase intentions and it is essential to investigate it for both theoretical and managerial purposes.

Having that in mind, in line with the European Commission attempts to create the unique green market comprising the EU countries, this paper examines green purchase intentions in the context of Croatian and Swedish consumers. According to the Eurobarometer research (2013), the two countries differ greatly when it comes to the percentage of regular green consumers. Sweden is at the very top with $89 \%$, while Croatia has only $24 \%$ of regular green consumers. After a brief introduction, hypothesis justifications are explained in theoretical background, which is followed by methodology, results and discussion parts. The paper ends with the main conclusions of the research.

\section{THEORETICAL BACKGROUND}

Green marketing. Green marketing is a way in which companies can achieve financial goals by satisfying consumers' demands and needs that come from society's shift in environmental awareness. More precisely, companies should be held accountable for ethical choices of the sources of their raw materials, products as well as services and processes (Khan, Royhan, Rahman, Rahman \& Mostaf, 2019). The concept of green marketing strategy includes marketing procedures, practices and policies congruent with ecological awareness that eliminate and/ or reduce negative impact on nature and people (Zhang, Shen \& Wu, 2011). Hence, business activities need the support of a coordinated set of marketing activities (like product and package design, distribution channel, promotion activities, pricing etc.) as they represent the firm's value offering with the purpose of achieving economic goals (Taghian, Polonsky \& D'Souza, 2016; Davari \& Strutton, 2014; Pomering, 2017; Mahmoud, Ibrahim, Ali \& Bleady, 2017; Prakash \& Pathak, 2017). In a broad sense, green marketing includes green product / service development and the creation of price, promotion and distribution tactics aiming at promoting environmental safety and welfare (Kinoti, 2011). One of the main differences between the green and traditional marketing mix is greater value the green marketing mix creates to satisfy pro-envi- 


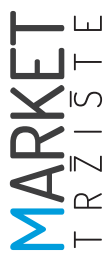

ronmental and societal needs, rather than economic goals alone (Chan, He \& Wang, 2012).

Green products. Higher concern for protecting natural resources from human activities has additionally highlighted the issues of environmental protection and environmentally conscious consumer behaviour. Consequently, it has increased the demand for green products (Kumar \& Ghodeswar, 2015). Words like green products, sustainable, ecological and environmentally friendly have frequently been used as synonyms to advise and attract consumers as a part of green marketing (Gosavi, 2013). It is believed that green products are less toxic and more durable because they are produced from recycled materials using more environmentally friendly processes (Ottman, 1998). But green product cannot be defined only through "reduce, reuse, recycle" phrase (Kinoti, 2011). Defining it is complex since there is no such product that is completely green and/or sustainable, as all products that are bought, consumed and discarded have a harmful environmental impact at some point in their lifecycles. However, they can be classified regarding the level of these impacts. The lower the negative impact of a product on the environment, the more environmentally sustainable it is (Pickett-Baker \& Ozaki, 2008). Many researches, like D'Souza and others (2006), have examined the consumption of green products over their lifecycles, starting with product development and materials used in manufacturing processes, storage and distribution activities, as well as consumptions and post-consumption activities. However, for the purpose of this study a green product is defined as "a product that was manufactured using toxic-free ingredients and environmentally friendly procedures, and which is certified as such by a recognized organization" (Gurau \& Ranchhod, 2005).

Green product quality. Consumers' knowledge about and experience with green products are factors that influence green purchase decisions (Laroche, Bergeron \& Barbaro-Forleo, 2011). Green products, to different degrees, endorse their positive or at least less negative envi- ronmental influence, while non-green products do not acknowledge their negative environmental impacts. Research (Esty \& Winston, 2006; D'Souza et al., 2006) has shown that consumers continue to express concern towards the quality of environmental products, due to belief that in order for a product to be green there must be a trade-off on quality.

According to Borin, Krishnan and Mullikin (2013), consumers perceive green products as environmentally safe, but question their quality. For many product categories, they are uncertain that green products can achieve both goals: be safe for the environment and be efficient. In addition to educating consumers about green product benefits in terms of the environment, companies must not compromise on product quality (D'Souza et al., 2006; Chen \& Chang, 2012; Luzio \& Lemke, 2013). At the same time, companies need to monitor and manage consumers' perception of greenness of their products, but also need to be aware that most consumers are not willing to sacrifice quality, functionality, price and general value that traditional products can offer. In that sense, the attributes of green products must at least match the attributes of traditional, non-green products to attract and keep consumers (Chen \& Chang, 2012). Therefore, the following hypothesis arises:

H1 Consumers that perceive the quality of green products as equal to or higher than the quality of conventional products are more likely to express green purchase intention.

Eco-labels. A very important and rising issue in sustainability studies is the role of eco-labels in shaping buyers' behaviour and their purchasing decisions. Environmental labelling is an effective way of communicating specific benefits of a product (D'Souza et al., 2006). Eco-labels can be defined as statements declaring that a product or service has specific green characteristics and properties (Kärnä, Hansen \& Juslin, 2003). Eco-labels facilitate identification of such products that have a reduced environmental impact throughout their life-cycle - from product de- 
velopment and production, to its use and disposal (Brécard, 2017).

Eco-labels make green products more recognizable and eco claims more authentic (Dangelico \& Pujari, 2010). According to Rahbar and Wahid (2011), eco-labels decrease information asymmetry between producer and consumer, and have to achieve the following main goals for consumers: provide information about intangible product characteristics and communicate higher value of green products. Environmental labels are expected to shape or modify buying behaviour, as consumers are willing to search for environmental information about products (D'Souza et al., 2006). Despite their purpose of enhancing purchase decision, customers are sometimes inadequately informed about their value, and therefore sceptical towards them. From the foregoing, the following hypothesis arises:

H2 Consumers that trust eco-labels on green product packaging are more likely to express green purchase intention.

Green price. Price is an important element of a marketing mix and a critical factor affecting consumers' choice behaviour. Most consumers are willing to pay a premium price if they perceive an additional value from the product (Mahmoud et al., 2017; Tang, Wang \& Lu, 2014). Environmental benefits of a product can be the reason for a consumer to choose one product over another of the same value and quality (Singh, 2013). Green pricing considers people and environment in addition to profit, in the sense that it considers employees' and community wellbeing while ensuring efficient production processes (Shil, 2012). A research on bridging the value-action gap in green purchase behaviour by Asgari, Siew and Weisstein (2014) showed that effective price communication and price promotions affect green purchases positively.

According to the prospect theory explained by Kahneman and Tversky (1979), consumers are more sensitive to loss than gain. Hence, green product value communication should strive to decrease perceived loss (higher price) and increase psychological gains from green product consumption. A higher price of a green product can be a formative factor for some consumers and it is considered one of the most important obstacles for purchasing green products (Solvalier, 2010; Nguyen, Lobo \& Greenland, 2017). All these factors should be taken into consideration when deciding on the price of green products:

H3 Consumers who perceive the price of green products as higher than the price of conventional products are less likely to express green purchase intention.

Green place. In a broader sense, a green place refers to activities related to logistics and transportation, aiming at reducing carbon footprint. It concerns the distribution of green products that is beneficial for customers as it enhances product delivery and secures cycling procedures by fulfilling internal environmental requirements (Shil, 2012; Hashem \& Al-Rifai, 2011). In the context of the present study, it refers to the location where products can be acquired, i.e. physical stores. The decision about the place where products can be bought can have a crucial influence on consumers' purchase decisions. Very few customers are willing to go out of their way and make an additional effort to buy green products (Sharma, 2011).

It is of great importance to ensure that green products are widely available in order to endorse green purchase behaviour. Producers can influence retailers by persuading them to offer green products by giving promotion support (Nguyen et al., 2017). A research conducted in Sweden by Anselmsson and Johansson (2007) showed that retail stores present an important touchpoint between consumers and green products because they can provide additional information when it comes to green product characteristics. Scarce availability of green products is proved to be one of the main barriers in making green purchase decisions, since it may require consumers to visit specialized stores and they associate it with extra effort (Nguyen et al.,

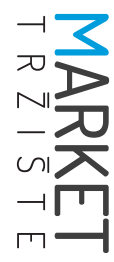




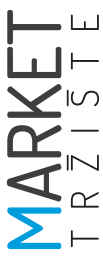

2017; Solomon, Bamossy, Askegaard \& Hogg, 2010; Majlath, 2010; Barbarossa \& Pastore, 2015; Essoussi \& Zahaf, 2008). It is therefore suggested that:

H4 Consumers who find green products more available at the marketplace are more likely to express green purchase intention.

Green promotion. Marketing communication refers to communicating values and ideas to consumers in order to persuade them to buy products (D'Souza et al., 2006). Green promotion is designed to inform consumers and other stakeholders about company's business, environmental concern and accomplishments toward protecting the environment (Dahlstrom, 2011).

As a response to an increasing demand for environmentally friendly products, green advertising appeals became a significant part of promotion activities for many products (European Commission, 2014; Segev, Hong \& Fernandes, 2016). However, many green ads communicate unclear trust and lack transparent and straightforward information about products' green attributes (Baum, 2012). This can be referred to as 'greenwashing', that is the act of deceiving consumers about green practices or products' environmental benefits (Carlson, Grove \& Kangun, 1993; Parguel, Benoit-Moreau \& Russell, 2015). It is impossible for consumers to verify environmental benefits of a product, even after consuming a product claiming to have those benefits (Carlson et al., 1993; Lyon \& Maxwell, 2011). Consequently, the untruthful and deceitful promotion of products' environmental aspects can lead to decreasing consumer trust in green advertising (Chen \& Chang, 2012; Parguel et al., 2015). Considering everything stated above, the following hypothesis is proposed:

H5 Consumers that are sceptical about green product ads are less likely to express green purchase intention.

Green consumers. Ethically minded consumers believe they are responsible towards the environment and they try to communicate their values through green purchasing behaviour and consumption (De Pelsmacker, Driesden \& Rayp, 2005; Shaw \& Shiu, 2002). Roberts (1996) defines ecologically conscious consumers as those who purchase and consume only those products with low negative influence on the environment. On the other hand, a green consumer can be defined as being aware of the connection between purchasing and consuming products and at the same time is responsible towards the environment (Hailes, 2007). Green consumers know that by avoiding products that are harmful to the environment, they can contribute to environmental wellbeing. Hence, they attempt not to buy products that are perceived as risky for human health, harmful to the environment, products with additional packaging, and those made of ingredients that come from unsustainable sources.

Anderson and Cunningham (1972) define green consumers as those individuals who are not only oriented toward satisfying their own needs, but are at the same time concerned with the wellbeing of the environment and the society as a whole. They described the average green consumer as a highly educated 40-year-old woman, with above average socio-economic status. However, the results from later research (Kinnear \& Taylor, 1973; Hines, Hungerford \& Tomera, 1987; Peattie, 1995; Akerhurst, Afonso \& Goncalves, 2012; Albayak, Aksoy \& Caber, 2013) show that socio-demographic variables are not as important in describing green consumer behaviour as it was reported in earlier research. On the other hand, psychographic and behavioural variables, such as environmental awareness, perceived consumer effectiveness (PCE) and altruism, are proved to be more effective in portraying and understanding environmentally conscious consumer behaviour. Research by Essoussi and Zahaf (2008) that examined green consumers in Canada proposed that PCE and environmental awareness have significant positive impact on green product purchase when it comes to food products. These results are in line with an earli- 
er research showing that interaction of the two variables is crucial for making green purchase decisions (Roberts \& Straughan, 1996).

Environmental awareness. Environmental awareness is frequently defined as "a personal awareness of the environmental problems and willingness to take part in solving the problem" (Dunlap \& Jones, 2002; Chan \& Lau, 2002). It is connected with knowledge level and emotions as well as willingness to change behaviour. Much of the early research on green consumers confirmed a positive correlation between environmental awareness and environmentally friendly behaviour (Akerhurst et al., 2012).

Nevertheless, it is important to mention the 'attitude-behaviour gap' or 'value-action gap', which explains why sometimes purchase decisions of consumers with high level of environmental concern do not reflect their concern for the environment (Young, Hwang, McDonald \& Oates, 2010). Some authors (Biel \& Dahlstrand, 2005; Sener \& Hazer, 2008) propose that 'value-action gap' could be affected by reasons such as brand strength, lifestyle, demographic characteristic and culture, as well as a lack of information or finance. With the goal of finding unique characteristics among green consumers from different cultures, the following hypothesis is proposed:

H6 Environmentally conscious consumers are more likely to express green purchase intention.

Perceived consumer effectiveness. Consumers' environmental concern may not automatically be translated into green purchase behaviour unless they believe that they, as individuals, can have an impact on solving environmental problems (Roberts \& Straughan, 1999). Based on Follows and Jobber's (2000) and Moisander's (2007) research, it can be concluded that the decision to purchase an alternative to a particular product requires a well-thought and conscious knowledge of its consequences. In other words, the purchase intention is a consequence of an evaluation of the trade-off between personal and environmental costs. In an environmental study, PCE can be defined as "an internal locus of control held by consumer that one's own actions can make a difference in protecting the environment" (Cleveland, Kalamas \& Laroche, 2012). Additionally, Kinnear, Taylor and Ahmed (1974) define PCE as the degree of an individual's confidence in their personal efforts towards resolving problems. In the field of green consumption, PCE is a critical predictor of green behavioural intention, meaning it is an important prerequisite for predicting consumers' green purchasing behaviour (Vermeir \& Verbeke, 2008; Ellen, Wiener \& Cobb-Walgren, 1991; Roberts, 1996). The following is therefore proposed:

H7 Consumers with high level of PCE are more likely to express green purchase intention.

\section{RESEARCH}

\subsection{Methodology and results}

To test the hypotheses, a survey was conducted on a convenience sample of 206 respondents from the Republic of Croatia $(n=103)$ and Sweden $(n=103)$. Those two countries were chosen because they represent two different contexts regarding consumers' green purchase behaviour and companies' green marketing activities. Moreover, they represent countries with two different stages of economic and social development, which is very important for researching topics such as sustainability and green consumer behaviour.

To collect the data, a self-administered highly structured questionnaire consisting of 28 questions was used. The first group of questions was about sample characteristics (age, gender, nationality, education - see Table 1). The aim of the second group of questions was to investigate whether respondents buy green products or not, and in which product categories. Additionally, reasons for not buying them were also to be identified. The final group of questions was related to testing the hypotheses and it 
contained the questions that measured respondents (dis)agreement with claims about green marketing mix, environmental awareness and green purchase intentions (Chang \& Chen, 2012; D'Souza et al., 2006; Khare, 2014; Pickett-Baker \& Ozaki, 2008). The questionnaire was distributed in two languages (Croatian and English) using "back-to-back translation". For data analyses, SPSS was used.

Out of the 103 respondents from Croatia, 80 of them expressed willingness to buy green products (food and cosmetics as product categories were most common answers) while 23 did not (the reasons were high price of such products and a lack of their availability in stores). On the other hand, 91 Swedish respondents expressed willingness to buy green products (beside food and cosmetics, clothes, detergents and furniture were mentioned as well), while only 12 of them had different opinion (mostly because of high price, personal indifference regarding green products and because they do not un- derstand the benefits of green products over conventional ones).

For testing the hypotheses, Pearson correlation and regression analyses were used. The results are shown in tables 2 and 3.

The data presented in Table 2 show that for Croatian consumers there is correlation between perceived green product quality, trust in eco-labels, green products availability, environmental awareness and PCE, and green purchase intension. On the other hand, in the context of Swedish respondents, correlation with green purchase intentions in visible only for perceived green product quality, scepticism toward ads for green products and environmental awareness. Having that in mind, results presented in Table 3 are not surprising. According to regression analyses results, only perceived green product quality and environmental awareness have positive and significant influence on green purchase intentions.

\section{TABLE 1: Sample characteristics}

\begin{tabular}{|c|c|c|c|c|}
\hline \multirow[b]{2}{*}{ Total number } & \multicolumn{2}{|c|}{ Croatia } & \multicolumn{2}{|c|}{ Sweden } \\
\hline & 103 & $100 \%$ & 103 & $100 \%$ \\
\hline \multicolumn{5}{|l|}{ Gender } \\
\hline Male & 25 & $24,27 \%$ & 45 & $43,96 \%$ \\
\hline Female & 78 & $75,73 \%$ & 58 & $56,31 \%$ \\
\hline \multicolumn{5}{|l|}{ Age } \\
\hline $18-25$ & 78 & $75,73 \%$ & 23 & $22,33 \%$ \\
\hline $26-40$ & 25 & $24,27 \%$ & 64 & $62,14 \%$ \\
\hline $41-55$ & 0 & $0 \%$ & 10 & $9,71 \%$ \\
\hline $56-65$ & 0 & $0 \%$ & 6 & $5,83 \%$ \\
\hline \multicolumn{5}{|l|}{ Education } \\
\hline High school & 20 & $19,42 \%$ & 7 & $6,8 \%$ \\
\hline College & 4 & $3,89 \%$ & 7 & $6,8 \%$ \\
\hline Bachelor Degree & 33 & $32,04 \%$ & 21 & $20,39 \%$ \\
\hline Master Degree & 44 & $42,72 \%$ & 44 & $42,72 \%$ \\
\hline $\mathrm{PhD}$ & 2 & $1,94 \%$ & 24 & $23,30 \%$ \\
\hline
\end{tabular}


TABLE 2: Correlation coefficient

\begin{tabular}{|c|c|c|c|}
\hline & \multicolumn{2}{|c|}{ Purchase intention } \\
\hline & & Croatia & Sweden \\
\hline \multirow{3}{*}{ Perceived green product quality } & Pearson Correlation & $.466^{* *}$ & $.294^{* *}$ \\
\hline & Sig. (2-tailed) &, 000 &, 005 \\
\hline & $\mathrm{N}$ & 80 & 91 \\
\hline \multirow{3}{*}{ Trust in eco-labels } & Pearson Correlation & $.364^{* *}$ & ,039 \\
\hline & Sig. (2-tailed) & ,001 & ,716 \\
\hline & $\mathrm{N}$ & 80 & 91 \\
\hline \multirow{3}{*}{ Perceived higher price of a green products } & Pearson Correlation &, 113 &,- 016 \\
\hline & Sig. (2-tailed) & ,317 & ,878 \\
\hline & $\mathrm{N}$ & 80 & 91 \\
\hline \multirow{3}{*}{ Green products availability } & Pearson Correlation & $.274^{*}$ & 184 \\
\hline & Sig. (2-tailed) & ,014 & ,081 \\
\hline & $\mathrm{N}$ & 80 & 91 \\
\hline \multirow{3}{*}{ Scepticism toward ads for green products } & Pearson Correlation &,- 078 & $.294^{* *}$ \\
\hline & Sig. (2-tailed) &, 490 &, 005 \\
\hline & N & 80 & 91 \\
\hline \multirow{3}{*}{ Environmental awareness } & Pearson Correlation & $.242^{*}$ & $.368^{* *}$ \\
\hline & Sig. (2-tailed) & ,031 &, 000 \\
\hline & N & 80 & 91 \\
\hline \multirow{3}{*}{ Perceived consumer effectiveness } & Pearson Correlation & $.293^{* *}$ &,- 046 \\
\hline & Sig. (2-tailed) &, 008 & ,667 \\
\hline & N & 80 & 91 \\
\hline
\end{tabular}

According to research results, hypotheses $\mathrm{H} 1$ (Consumers that perceive green product quality equal or higher than the conventional products are more likely to express green purchase intention) and $\mathrm{H} 6$ (Environmentally conscious consumers are more likely to express green purchase intention) can be accepted, while others cannot be.

\subsection{Discussion}

Our research contributes to green marketing mix and green consumer literature by examining the elements of green marketing mix together with two important psychographic and behavioural characteristics of green consum- ers: environmental awareness and perceived consumer effectiveness. Moreover, it examines them in two different cultural, political and economic contexts of Croatian and Swedish consumers. The following theoretical and managerial implications arise from this study.

\section{Theoretical implications}

An important finding in our results implicates that neither Swedish nor Croatian consumers are willing to compromise on the quality of green products, and those who perceive green product quality as equal to or higher than traditional products are more willing to express green purchase intentions, as has been pro- 
TABLE 3: Regression analyses

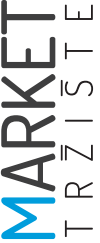

\begin{tabular}{|c|c|c|c|c|c|c|c|c|}
\hline & \multicolumn{2}{|c|}{$\begin{array}{c}\text { Unstandardized } \\
\text { Coefficients }\end{array}$} & \multirow{2}{*}{\begin{tabular}{|c} 
Standardized \\
Coefficients \\
Beta
\end{tabular}} & \multirow{2}{*}{$\mathbf{t}$} & \multirow{2}{*}{ Sig. } & \multicolumn{3}{|c|}{ Correlations } \\
\hline & B & $\begin{array}{l}\text { Std. } \\
\text { Error }\end{array}$ & & & & $\begin{array}{l}\text { Zero- } \\
\text { order }\end{array}$ & Partial & Part \\
\hline (Constant) & 4,576 & ,938 & & 4,876 &, 000 & & & \\
\hline $\begin{array}{l}\text { Perceived green } \\
\text { product quality }\end{array}$ & ,221 & ,057 & ,320 & 3,908 &, 000 & ,382 & 293 & ,263 \\
\hline Trust in eco-labels &, 022 &, 069 &, 025 &, 320 & ,749 & 248 &, 025 &, 022 \\
\hline $\begin{array}{l}\text { Perceived higher } \\
\text { price of a green } \\
\text { products }\end{array}$ &,- 038 & ,052 &,- 052 &,- 731 &, 466 & ,062 &,- 057 &,- 049 \\
\hline $\begin{array}{l}\text { Green products } \\
\text { availability }\end{array}$ & ,071 &, 044 &, 125 & 1,614 & , 109 & ,307 &, 125 & , 109 \\
\hline $\begin{array}{l}\text { Scepticism toward } \\
\text { green products' ads }\end{array}$ & ,069 &, 074 &, 065 & ,938 & ,350 & ,099 &, 073 &, 063 \\
\hline $\begin{array}{l}\text { Environmental } \\
\text { awareness }\end{array}$ &, 141 & ,039 & ,261 & 3,622 &, 000 & ,371 & 273 & ,244 \\
\hline $\begin{array}{l}\text { Perceived consumer } \\
\text { effectiveness }\end{array}$ &,- 083 &, 060 &,- 098 & $-1,367$ & , 173 &, 044 &,- 106 &,- 092 \\
\hline
\end{tabular}

posed by the existing findings in research on green products (D'Souza et al., 2006; Chen \& Chang, 2012; Luzio \& Lemke, 2013). Another finding, confirmed for both groups of consumers, is that a higher price of green product does not affect green purchase intentions negatively. It indicates that green consumers perceive premium prices of green products as an additional product value which is positively correlated with green purchase behaviour (Mahmoud et al., 2017; Tang, Wang \& Lu, 2014). Regarding green consumer characteristics, the level of environmental awareness has a positive relationship with green purchase behaviour, which shows that 'value-action gap', i.e. not translating environmental concern into purchase decisions does not depend on culture, demographic characteristics or lifestyle, as proposed by earlier research (Biel \& Dahlstrand, 2005; Sener \& Hazer, 2008; Wheale \& Hinton, 2007).

Eco-labels as an effective way of communicating specific benefits of a product (D'Souza et al.,
2006) do not have a positive effect on Swedish consumers, while the trust in eco-labels affects green purchase intentions positively for Croatian consumers. This supports the findings of the European Commission (2013), according to which Sweden has $89 \%$ of regular green consumers, while Croatia has only $24 \%$. The latter suggests that once green products become widely available and green consumer behaviour is mainstream, eco-labels no longer play a significant role in purchase decisions, and do not differentiate products in the marketplace. Another finding from the study has origins in the maturity of green market and the already established norms - green place. Wide availability of green products plays an important role for Croatian consumers, who are not willing to go out of their way to buy green products. On the other hand, it does not affect purchase decision of Swedish consumers because they do not have to go out their way to buy green products, since they are not considered special, but rather 
mainstream products in Sweden, and are therefore widely available.

Consumers' environmental concern may not necessarily be translated into green purchase behaviour, unless they believe that they, as individuals, can have an impact on solving environmental problems (Roberts \& Straughan, 1999). This has been confirmed by this research only in the case of Croatian consumers. Cultural differences between the two countries may offer a solid explanation, since Croatia is considered a collectivistic society, unlike Sweden, which is highly individualistic.

While scepticism toward green product ads has a negative impact on green purchase intentions for Croatian consumers, there is an interesting influence of scepticism towards green product ads in relation to purchase intention for Swedes. That is, the more sceptical they are, the more likely they are to buy. A possible explanation is the way the question about green product ads was posed in the survey. Specifically, the first question related to scepticism actually measures the awareness of green product ads. When viewed separately from the intention, it is positive, while for the other question examining scepticism, that relationship is neutral. It follows that Swedish consumers who pay attention to ads will more often express their intention to buy, while scepticism does not influence the intention, but the overall relationship remains positive.

\section{Managerial implications}

Despite the positive image of green products in relation to their environmental impact, companies must not compromise on the quality of green products compared to the traditional ones. Another critical part of the marketing mix that must not be compromised regardless of the consumer background is price. Since premium price is found to be an important communicator of green product additional value, lowering the price could imply that green product's quality has been decreased, which could have a negative impact on green purchase intentions.

Eco-labelling of green products can still be an effective way of differentiating products in a market that is not as developed or saturated with green products. However, marketeers in more developed markets, such as Sweden, must not rely on eco-labels as a differentiator since they have already become a standard. The same applies to availability of green products in conventional stores, which plays an important role for Croatian consumers, meaning there is room for increasing the availability of green products in order to lower the effort consumers have to make to obtain them.

Considering both the findings about perceived consumer effectiveness and scepticism towards green products ads, an important practical implication is found for both markets. Green product ads communicated in the Croatian market should aim at increasing the authenticity of claims in the ads. On the other hand, ads in Sweden could use claims that communicate and encourage perceived consumer effectiveness and importance of individual contribution to the society.

\subsection{Limitations and future research}

The main limitation of the research is that it includes only low-involvement products and neglects more complex purchase decisions. Another limitation is related to the domain of green consumers and responsible behaviour towards the environment, which implies that respondents may respond in socially desirable way instead of expressing their true attitudes and behaviours.

Further research on better understanding of green consumers should aim at observing habits and behaviours related to green purchases and complementing the results with the ones from the questionnaire, to see to what extent green consumers truly commit to their words.

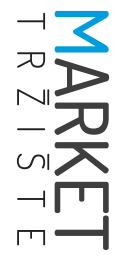




\section{CONCLUSIONS}

Sustainability remains an important global trend that simultaneously shapes the behaviour of both consumers and companies. As a consequence of this interplay, new lifestyles, products and services constantly emerge. Hence, it is of great importance to understand green products and green consumers better for both marketing practitioners and academics. The challenge in understanding the green marketing mix lies not only in the complexity of the definition, but also in the fact that it highly depends on the market context.

To summarise, with the aim of understanding green consumers and the green marketing mix better, this paper examined them in two very different environments: Swedish and Croatian. On the side of the marketing mix, green product quality and premium price should not be compromised, regardless of the nationality. When it comes to green consumer behaviour, both Swedish and Croatian consumers who express high levels of environmental awareness are also more likely to express green purchase intentions. Three out of seven factors have the same correlation with green purchase intention in case of both countries, which indicates some similarities between the countries. However, the differences prevail. These differences arise from the levels of the green market maturity, where Sweden is one of the top ranked countries in green activities, while Croatia is lagging behind. Cultural traits, such as individualism and collectivism, also play an important role in understanding green consumer behaviour, since they affect the extent to which individuals believe they can contribute to societal issues. An underlying conclusion for academics and practitioners in both countries is that green marketing mix can not be shaped in an effective and successful manner unless aligned with deeper understanding of psychological and behavioural forces shaping green consumer behaviour.

\section{REFERENCES}

1. Abdulrazak, S., \& Quoquab, F. (2018). Exploring Consumers' Motivations for Sustainable Consumption: A Self-Deterministic Approach. Journal of International Consumer Marketing, 30(1), 14-28.

2. Akehurst, G., Afonso, C., \& Gonçalves, H. (2012). Re-examining green purchase behavior and the green consumer profile: New evidences. Management Decision, 50(5), 972-988.

3. Albayrak, T., Aksoy, S., \& Caber, M. (2013). The effect of environmental concern and skepticism on green purchase behavior. Marketing Intelligence \& Planning, 31(1), 27-39.

4. Anderson, W. T., \& Cunningham, W. H. (1972). The Socially Conscious Consumer. Journal of Marketing, 36(3), 23-31.

5. Anselmsson, J., \& Johansson, U. (2007). Corporate social responsibility and the positioning of grocery brands: an exploratory study of retailer and manufacturer brands at point of purchase. International Journal of Retail \& Distribution Management, 35(1), 835-856.

6. Asgari, M., Siew, S. W., \& Weisstein, F. L. (2014). Price presentation effects on green purchase intentions. Journal of Product \& Brand Management, 23(3), 230-239.

7. Barbarossa, C. \& Pastore, A. (2015). Why environmentally conscious consumers do not purchase green products: A cognitive mapping approach. Qualitative Market Research: An International Journal, 18(2), 188-209.

8. Baum, L. M. (2012). It's Not Easy Being Green... Or Is It? A Content Analysis of Environmental Claims in Magazine Advertisements from the United States and United Kingdom. Journal of Nature and Culture, 6(4), 423-440.

9. Biel, A., \& Dahlstrand, U. (2005). Values and habits: a dual-process model. In Environment, Information and Consumer Behavior. Cheltenham: Edward Elgar. 
10. Borin, N., Krishnan, R., \& Mullikin, J. L. (2013). An analysis of consumer reactions to green strategies. Journal of Product \& Brand Management, 22(2), 118-128.

11. Brécard, D. (2017). Consumer misperception of eco-labels, green market structure and welfare. Journal of Regulatory Economics, 51(3), 340-364.

12. Carlson, L., Grove, S. J., \& Kangun, N. (1993). A Content Analysis of Environmental Advertising Claims: A matrix approach method. Journal of Advertising, 22(3), 27-39.

13. Chan, R., \& Lau, L. (2002). Explaining Green Purchasing Behavior: A Cross-Cultural Study on American and Chinese Consumers. Journal of International Consumer Marketing, 14(2/3), 9-40.

14. Chan, H. K., He, H., \& Wang, W. Y. (2012). Green marketing and its impact on supply chain management in industrial markets. Industrial Marketing Management, 41, 557-562.

15. Chen Y. S., \& Chang, C. H. (2012). Enhance green purchase intentions: The roles of green perceived value, green perceived risk, and green trust. Management Decision, 50(3), 502-520.

16. Cleveland, M., Kalamas, M., \& Laroche, M. (2012). It's not Easy Being Green: Exploring Green Creeds, Green Deeds, and Internal Environmental Locus of Control. Psychology \& Marketing, 29(5), 293-305.

17. D'Souza, C., Taghian, M., Lamb, P., \& Peretiatkos, R. (2006). Green products and corporate strategy: an empirical investigation. Society and Business Review, 1(2), 144-157.

18. Dahlstrom, R. (2011). Green marketing management. Sydney: Cengage Learning

19. Dangelico, R. M., \& Pujari, D. (2010) Mainstreaming Green Product Innovation: Why and How Companies Integrate Environmental Sustainability. Journal of Business Ethics, 95, 471-486.

20. Davari, A., \& Strutton, D. (2014) Marketing mix strategies for closing the gap between green consumers' pro-environmental beliefs and behaviors. Journal of Strategic Marketing, 22, 563-586.

21. De Pelsmacker, P., Driesden, L., \& Rayp, G. (2005). Do Consumers Care about Ethics? Willingness to Pay for Fair-Trade Coffee. Journal of Consumer Affairs, 39(2), 363-385.

22. Dunlap, R. E., \& Robert E. J. (2002). Environmental Concern: Conceptual and Measurement Issues. In: R. E. Dunlap \& W. Michelson (eds.). Handbook of Environmental Sociology (pp. 482-524). Westport, CT: Greenwood Press.

23. Ellen, P., Wiener, J., \& Cobb-Walgren, C. (1991). The Role of Perceived Consumer Effectiveness in Motivating Environmentally Conscious Behaviors. Journal of Public Policy \& Marketing, 1, 43-57.

24. Essoussi, H. L. \& Zahaf, M. (2008). Decision making process of community organic food consumers: An exploratory study. Journal of Consumer Marketing, 25, 95-104.

25. Esty, D., \& Winston, A. (2006). Green to Gold: How Smart Companies Use Environmental Strategy to Innovate, Create Value, and Build Competitive Advantage. New Haven, CT: Yale University Press.

26. European Commision (2013). Attitudes of Europeans towards building the single market for green products, Flash Eurobarometer 367. Available at: https://ec.europa.eu/commfrontoffice/ publicopinion/flash/fl_367_en.pdf

27. European Commission (2014). Consumer Market study on environmental claims for non-food products. Available at: https://ec.europa.eu/info/sites/info/files/study_on_environmetal_claims_for_ non_food_products_2014_en.pdf

28. European Commission (2017). Attitudes of European citizens towards the environment, Special Eurobarometer 468. Available at: https://ec.europa.eu/environment/eurobarometers_en.htm

29. Follows, S., \& Jobber, D. (2000). Environmentally responsible purchase behavior: A test of a consumer model. European Journal of Marketing, 34, 723-746.

30. Gosavi, P. S. (2013). Gaining competitive advantage through green marketing of cell phone. ASM's International E-Journal of Ongoing Research in Management and IT, 13(1), 1-11.

31. Gurau, C., \& Ranchhod, A. (2005). International green marketing: A comparative study of British and Romanian firms. International Marketing Review, 22(5), 574-561. 
32. Hailes, J. (2007). The new green consumer guide. London: Simon \& Schuster.

33. Haron, S. A., Paim, L., \& Yahaya, N. (2005). Towards sustainable consumption: an examination of environmental knowledge among Malaysians. International Journal of Consumer Studies, 29(5), 426-436.

34. Hashem, T. N., \& Al-Rifai, N. A. (2011). The influence of applying green marketing mix by chemical industries companies in three Arab States in West Asia on consumer's mental image. International Journal of Business and Social Science, 2(3), 92-101.

35. Hines, J. M., Hungerford, H. R., \& Tomera, A. N. (1987) Analysis and synthesis of research on responsible environmental behavior: A meta-analysis. Journal of Environmental Education, 18(2), 129-153.

36. Kahneman, D. \& Tversky, A. (1979). Prospect theory: an analysis of decision under risk. Econometrica, 47(2), 263-292.

37. Kärnä, J., Hansen, E., \& Juslin, H. (2003). Social responsibility in environmental marketing planning. European Journal of Marketing, 37(5/6), 848-871.

38. Khan, E. A., Royhan, P., Rahman, M. A., Rahman, M. M., \& Mostafa, A. (2019). The Impact of Enviropreneurial Orientation on Small Firms' Business Performance: The Mediation of Green Marketing Mix and Eco-Labeling Strategies. Sustainability, 12, 221-232.

39. Khare, A. (2014). Consumers' susceptibility to interpersonal influence as a determining factor of ecologically conscious behavior. Marketing Intelligence \& Planning, 32(1), 2-20.

40. Kinnear, T. C., \& Taylor, J. R. (1973). The effect of ecological concern on brand perceptions. Journal of Marketing, 10, 191-197.

41. Kinnear, T. C., Taylor, J. R., \& Ahmed, S. A. (1974). Ecologically concerned consumers: Who are they?. Journal of Marketing, 38(2), 20-24.

42. Kinoti, M. W. (2011). Green marketing intervention strategies and sustainable development: A conceptual paper. International Journal of Business and Social Science, 2, 263-273.

43. Kumar, P., \& Ghodeswar, B. M. (2015). Factors affecting consumers' green product purchase decisions. Marketing Intelligence \& Planning, 33(3), 330-347.

44. Laroche, M., Bergeron, J., \& Barbaro-Forleo, G. (2001). Targeting consumers who are willing to pay more for the environmentally friendly products. Journal of Consumer Marketing, 18(6), 503-520.

45. Luzio, J. P., \& Lemke, F. (2013). Exploring green consumers' product demands and consumption processes: The case of Portuguese green consumers. European Business Review, 25(3), 281-300.

46. Lyon, T. P., \& Maxwell, J. W. (2011). Greenwash: Corporate Environmental Disclosure Under Threat of Audit. Journal of Economics \& Management Strategy, 20(1), 3-41.

47. Mahmoud, T. O., Ibrahim, S. B., Ali, H. A., \& Bleady, A. (2017). The Influence of Green Marketing Mix on Purchase Intention: The Mediation Role of Environmental Knowledge. International Journal of Scientific \& Engineering Research, 8(9), 1040-1048.

48. Majlath, M. (2010). Can Individuals do anything for the Environment? The Role of Perceived Consumer Effectiveness. FIKUSZ'10 Symposium for Young Researchers, Budapest.

49. Moisander, J. (2007). Motivational Complexity of Green Consumerism. International Journal of Consumer Studies, 31, 404-409

50. Nguyen, T. N., Lobo, A., \& Greenland, S. (2017). The influence of cultural values on green purchase behavior. Marketing Intelligence \& Planning, 35(3), 377-396.

51. Ottman, J. A. (1998). Green marketing: Opportunity for innovation. Lincolnwood, IL: Contemporary Books.

52. Parguel, B., Benoit-Moreau, F., \& Russell, C. A. (2015). Can evoking nature in advertising mislead consumers? The power of 'executional greenwashing'. International Journal of Advertising: The Review of Marketing Communications, 34(1), 107-134. 
53. Peattie, K. (1995). Environmental Marketing Management: Meeting the Green Challenge. London: Pitman Publishing.

54. Picket-Baker J., \& Ozaki, R. (2008). Pro-environmental products: marketing influence on consumer purchase decision. Journal of Consumer Marketing, 25(5), 281-293.

55. Pomering, A. (2017). Marketing for sustainability: Extending the conceptualization of the marketing mix to drive value for individuals and society at large. Australasian Marketing Journal, 25, 157-165.

56. Prakash, G., \& Pathak, P. (2017). Intention to buy eco-friendly packaged products among young consumers of India: A study on developing nation. Journal of Cleaner Production, 141, 385-393.

57. Rahbar, E., \& Wahid, N. A. (2011). Investigation of green marketing tools' effect on consumers' purchase behavior. Business Strategy Series, 12(2), 73-83.

58. Roberts, J. A. (1996). Will the socially responsible consumer please step forward?. Business Horizons, 39(1), 79-84.

59. Roberts, J., \& Straughan, R. (1999) Environmental segmentation alternatives: A look at green consumer behavior in the new millennium. Journal of Consumer Marketing, 16, 558-575.

60. Segev, S., Hong, C., \& Fernandes, J. (2016). Is Your Product Really Green? A Content Analysis to Reassess Green Advertising. Journal of Advertising, 45(1), 1-9.

61. Sener, A., \& Hazer, O. (2008). Values and sustainable consumption behavior of women: a Turkish sample. Sustainable Development, 16(5), 291-300.

62. Sharma, Y. (2011) Changing consumer behavior with respect to green marketing - a case study of consumer-durables and retailing. International Journal of Multidisciplinary Research, 1(4), 152162.

63. Shaw, D., \& Shiu, E. (2002). An assessment of ethical obligation and self-identity in ethical consumer decision-making: a structural equation modelling approach. International Journal of Consumer Studies, 26(4), 286-293.

64. Shil, P. (2012). Evolution and future of environmental marketing. Asia Pacific Journal of Marketing and Management Review, 1(3), 74-81.

65. Singh, G. (2013) Green: the new color of marketing in India. ASCl Journal of Management, 42(2), 52-72.

66. Solomon, M. R., Bamossy, G., Askegaard S., \& Hogg, M. K. (2010). Consumer Behavior: A European Perspective. New York, NY: Prentice Hall.

67. Solvalier, I. (2010). Green marketing strategies case study about ICA group AB. Karlstad: Karlstad University.

68. Taghian, M., Polonsky, M., \& D'Souza, C. (2016). Green marketing strategies. An Integrated Approach to Environmental Management. New York, NY: John Wiley \& Sons.

69. Tang, Y., Wang, X., \& Lu, P. (2014). Chinese consumer attitude and purchase intent towards green products. Asia-Pacific Journal of Business Administration, 6(2), 84-96.

70. Vermeir, I., \& Verbeke, W. (2008). Sustainable food consumption among young adults in Belgium: Theory of planned behavior and the role of confidence and values. Ecological Economics, 64(3), 542-553.

71. Wheale, P., \& Hinton, D. (2007) Ethical consumers in search of markets. Business Strategy and the Environment, 16(4), 302-315.

72. Young, W., Hwang, K., McDonald, S., \& Oates, C. J. (2010) Sustainable consumption: green consumer behavior when purchasing products. Sustainable Development, 18(1), 20-31.

73. Zhang, X., Shen, L., \&Wu, Y. (2011). Green strategy for gaining competitive advantage in housing development: A China study. Journal of Cleaner Production, 19, 157-167. 